\title{
PREMISES AND SCOPE OF THE PATENT CHAPTER
}

\section{Laurence I. Wood $\dagger$}

Probably the only constructive contribution that can be made in a symposium such as this by a concurring participant in the Committee's deliberations-unless he is to center his approach on answering those who have dissented-is to consider and expand on that which was not said in the Report. ${ }^{1}$ Although to do so may come perilously close to defining the non-existent, the unsaid things may properly be divided into two groups: that which was not said because it was fundamental to the thinking behind the Report, and, therefore, simply assumed; and that which was not said because it was deemed to be beyond the subject assigned to the Committee, and hence not assumed at all. Obviously, it can make a great deal of difference whether a nonstatement is assumed and presumed to be understood by the reader, or whether it is simply excluded. altogether from the area of communication between the writer and the reader. The first of these, at the very least, ought to be clearly delineated; it would be helpful if the latter were expressly set aside. A fair conclusion would be that the unsaid ought to be explicitly so!

In order to find out what the Patent Chapter has not said, we should look first briefly at what it has covered. In the thirty-eight pages devoted to this subject, ${ }^{2}$ the Report treats the philosophy and theory which underly the patent grant and spells out the reconciliation with the public interest of the private award to the inventor. It delineates the ways in which the patent grant is designed to achieve its public purpose, and it expressly states that a patent is a species of "personal property." 3

Moving forward from this introduction, the Report considers in detail the relationship of the patent grant to the antitrust laws and

† Counsel, Apparatus Sales Division, General Electric Co. Member, Attorney General's National Committee To Study the Antitrust Laws. A.B., De Pauw University; J.D., Northwestern University.

1. Report of the Attorney Generar's National Commttee To Study the ANTITRUST Laws (1955) (hereinafter cited as REPORT).

2. Id. at $223-60$.

3. Id. at 225 . 
the limitations which those laws impose upon the use and transfer of patents. Here are treated such subjects as the acquisition of patents and the varying problems presented by the different methods or circumstances in which this may occur. Here also is discussed the nonuse of patented inventions and the areas in which it may have antitrust overtones. Most lengthy of all is the section on patent licenses, which considers the various types of license limitations-price, field of use, quantity, territory and tying clauses-and the variant antitrust problems which may arise when these are included in single patent licenses, multiple patent licenses and cross-license agreements. The chapter next explores the difficult issues involving the interchange of patents, which is the Report's substitute expression for the semantically inept "patent pool." The Report considers also the antitrust problems that may arise out of patent infringement suits. It discusses in some detail the origin and nature of the patent misuse doctrine and the extent to which that is currently and erroneously enmeshed with antitrust principles. Finally, the Report considers the controversial problem of appropriate remedies insofar as patents are concerned where patents or patent practices have been involved in an antitrust situation.

Like the over-all Report, the Patent Chapter is concerned to no substantial extent with new or revised legislation. The conclusion of the Committee here, as in the other areas of the Report, was of the fundamental soundness and effectiveness of our existing antitrust laws. Here, as elsewhere, the Report is in its basic approach a careful and painstaking analysis and review of the decided cases in this branch of antitrust laws. The main theme of the Report throughout is its emphasis on the importance of the rule of reason approach to virtually every one of the antitrust problems presented. This atmosphere is particularly significant in the patent-antitrust area because of the virtual impossibility of codification or advance delineation of a cleavage between right and wrong in the borderline situations. A case by case examination of the acceptability of specified practices is called for, and it must be based on the rationalization of the public interest purposes served by both sets of laws.

It is here that we come to the first of the fundamental assumptions which runs implicitly throughout the Patent Chapter of the Report. This is the thesis that the patent system is designed to work in the public interest, through the promotion of industrial and economic progress, just as are the antitrust laws. The two sets of statutes take obviously different routes, but their goals - of stimulating progress and achievement on the one hand, and stimulating and protecting competition on the other-are much the same. 
The importance of this concept lies in the fact that only through its acceptance can there be any intelligent rationalization of the two bodies of law. There is indeed a surface anomaly in the existence of a statutory monopoly in a competitive economy. Actually, however, the patent grant is but one of a large number of monopolies accepted in an economy built on a complex interadjustment of diverse elements, ranging from the most severely competitive to the most rigidly restrictive. The patent grant has been well termed a "public welfare monopoly." 4 The patent monopoly, like competition itself, has been endorsed by governmental policy as a means to a greater end. The proper resolution of the conflicts which arise between the two groups of laws can only be undertaken in an environment which accords to them both an objective of furthering public policy. In this vein it is essential to emphasize the fact that while patents are granted to individual inventors, the purpose behind them is the benefit of society. This concept is one which has been ignored in much of the criticism leveled at the patent system during the past decade and a half. ${ }^{5}$ Yet, the importance of this "prima facie" approach runs through every aspect of patent law. It affects the manner in which patents are construed in patent infringement suits; it is enmeshed inevitably with the fluctuating standards of measurement as to what constitutes invention; and it is fundamental to the consideration of situations involving patents and the antitrust laws.

However, the converse is equally true. It has been emphasized frequently and forcefully that the incentive to invent and invest provided by the patent laws is an inherent part of the industrial achievement which has sparked our progress. But it must be fully evident that the competitive forces which are safeguarded by an alert antitrust policy are essential to the need for innovation and to the driving urge to get ahead of competitors-both of which create the market for the new inventions which the patent system identifies and protects. "Competition is the spark plug of our economy. It keeps us endlessly, urgently searching and researching for new and better products, more efficient methods of production, and surer marketing techniques. It is both the 'carrot' and the 'stick,' at once pulling and pushing us along the road to better things. Human nature being what it is, . . . there is no substitute for competition." ฐa

4. Oppenheim, The Public Interest in Legal Protection of Industrial and Intellectual Property, 40 TRADE-MARK RER. 613, 617 (1950).

5. See address by Oppenheim, Patents and Antitrust: Peaceful Coexistence?, ABA Annual Meeting, August 22, 1955.

5a. Address by Philip D. Reed, Convention of the National Foreign Trade Council, Nov. 14, 1955. 
It is an interesting coincidence that there was released in England, shortly after the publication of the Attorney General's Report in this country, The Monopolies and Restrictive Practices Commission's Report on Collective Discrimination. ${ }^{6}$ In this report, the British give evidence of learning from experience of the throttling effect upon innovation and progress which inheres in the restrictions of a cartelized world. The Commission's report discloses that the British economy is cut across in industry after industry with collective price agreements; with formal industry agreements to enforce the specified prices, organized boycotts to cut off buyers (or sellers) who do not observe the prices, organized group price discriminations against those who do not comply, organized industry wide enforcement of resale price maintenance agreements, and finally, industry "trade courts" to try and to impose penalties on those who disturb the even tenor of the collective ways. ${ }^{7}$

The Commission in December, 1952, was instructed to study the nature, scope and extent of these practices. By majority vote, it has concluded that these activities are against the public interest, and has recommended that legislation should be adopted prohibiting them except where ". . . cases may be found in which they are on balance advantageous." 8

From our standpoint the most significant conclusion of the Commission is as follows:

"Agreements. which bind suppliers to adopt common policies in laying down conditions of sale . . . seem to us likewise to prevent experiment and to protect established traders from the competition of those who would otherwise be willing to introduce new techniques and thus to create a rigidity in trading practices which is contrary to the public interest . . . . What is important, for the protection of the public interest, is that concerns which think other methods may be better should be able to try them without having to meet the organised opposition of the rest of the trade. The final verdict on which is the better method should be left to the market, where the consumer can exert his influence, and should not be reached by a collective decision of traders which prevents him from doing so." 9

6. Monopolies and Restrictive Practices Commission, Report on Collectrve Discrimination (1955) (hereinafter cited as Report on Collective DiscrminaTION).

7. It carefully confined itself to a study of these group activities (expressly excluding any study of the effect or propriety of individual action in these areas).

8. REPORT ON Collective Discrimination, supra note $6, \pi 246$, at 86 . The vote of the Committee was divided seven to three. The Parliamentary debates, 543 H.C. DEB. (27th ser.) 1940 et seq. (1955), 193 H.L. DEB. (23d ser.) 1081 et seq. (1955), disclose a marked lack of enthusiasm by the legislators for these recommendations.

9. Report on COLlective Discrnination, supra note $6, \pi 236$, at 82 . It is submitted that essentially the same lack of competitive spur to progress would follow 
The Commission was here discussing experiment and innovation concerning marketing techniques. ${ }^{10}$ It is, however, difficult to conceive of such a climate-half emergent from cartelization and socialization -as being conducive to innovation, experiment or risk of any kind. And with such a lack of competitive encouragement, the most salutary patent policy would scarcely serve to achieve industrial progress. It is, accordingly, essential to that progress that both the patent and the antitrust policies of the Government be preserved.

The second fundamental premise implicit in the Report to the Attorney General is that while patents do indeed by definition come within the scope of the word "monopoly," they are by no means necessarily commercially important monopolies. In fact, in more instances than not, patents constitute a right to exclude others from that which is a very minor, even miniscule, part of an economic area. This fact is tremendously significant in the approach of the Report, and it is one which must constantly be borne in mind in consideration of this whole area of the law. Semantics is often vitally important in dealing with any subject in the politico-economic area, wherein patent antitrust problems most assuredly lie. Where the nation's antitrust policy is directed so enthusiastically against "monopolies," against "exclusion of competition," and against "exclusive rights," there must be a constant reminder that the use of these identical terms when referring to patent practices does not connote like problems, but is a parlance peculiar to the special property involved. This use of similar expressions to refer to totally dissimilar problems makes more difficult the imperative application of rule of reason criteria to patent-antitrust problems as they arise. An arbitrary per se approach would be most unsatisfactory since it would preclude a search for the truth as to the existence of competitive products or patents or the actual impact on the relevant market of practices relating to a specific patent or patented product.

The importance of this premise is given emphasis in a rather special problem of patent-antitrust interpretation in the Report. The

the adoption of suggestions for the socialization or equalization of technical knowledge. $C f$. Hamilton, $A$ New Patent Policy, 17 Current History 338, 341 (1949): "The know-how essential to production should be made available to all the members of an industry on equal terms. . . A further step is desirable and may be necessary. The research laboratory, instead of belonging to a single corporation, might well be maintained by the industry."

10. Patent license agreements were expressly excluded from the scope of the inquiry. Id. $\| 5$, at 2 . 'The expression 'the specified practices' shall not, however include actions taken in the course of carrying out . . (b) agreements under which a license is granted by the proprietor of a patent or trade mark . . . for the manufacture or sale of goods to which no persons other than the proprietor and licensee are parties. ..." 
Supreme Court in the Times-Picayune ${ }^{11}$ case seemed to say by way of dicta that since patents are by definition a monopoly, they, therefore, automatically constitute the "monopolistic leverage" which, in the consideration of the validity of tying clauses, makes for illegality without more. In other words, the Supreme Court's interpretation of section 3 of the Clayton Act says that where any product which is monopolistic or which has a market control is tied either by lease or by sale to another product, illegality attaches. The Court seems to assume that the existence of patents in connection with a product automatically confers such a monopoly or such market control. It is not clear in the gleanings from that case whether the Court is saying this is automatically so or prima facie so. ${ }^{12}$

In either event, the criterion as thus expressed is altogether artificial and unsatisfactory. For obviously the only real test in determining market control is to ascertain whether or not there is in fact competition for the article. This does not depend on whether there are patents connected with it. It is true, of course, that there are articles which are the subject of patent protection to the extent that they are essentially free from competition; there are many more, however, parts of which may be covered by one or more patents of no competitive significance in the sense of removing the article from the forces of competition. It is this rationale which underlies the Committee's conclusion that "the patentee should be permitted to show that in the entire factual setting . . . the patent does not create the market power requisite to illegality of the tying clause." 13

It should be observed that this recommendation has been misread and erroneously criticized as applying to and vitiating the doctrine of the misuse of patents. Thus, one recent law review commentator states:

". . . this recommendation suggests that the patentee be permitted to exceed the bounds of his patent so long as he does not transgress criteria fixed by other laws." 14

11. Times-Picayune Publishing Co. v. United States, 345 U.S. 594 (1953).

12. Compare: "Patents . . supplied the requisite market control." Id. at 611 , verith: "A patent . . is at least prima facie evidence of [market] control." Ibid. (quoting from Standard Oil of California v. United States, 337 U.S. 293, 327 (1949)).

13. REPORT at 238 .

14. Diggins, The Patent-Antitrust Problem, 53 Mich. L. Rev. 1093, 1103 (1955). See also The Schwartz Dissent, 1 Antratrust Bull. 37, 62 (1955): "It is settled law that sale of a patented product on condition that the purchaser buy another product is an illegal abuse of patent power. The Majority Report however would change this to require the Government to prove that the patent was "broad and basic' before the tying clause becomes illegal." 
The author thus imputes to the Committee a conclusion that a patentee should be permitted to tie unpatented materials to a patent unless there is a showing of market dominance sufficient to constitute antitrust violation. This attack is, however, against a non-existent windmill. It fails to note the Committee's very determined effort to emphasize and preserve the distinction between a per se rule of antitrust violation and the existing per se misuse doctrine, which the Committee supports. The latter prohibits the patentee from suing an infringer while any such misuse as tying to a patent is taking place. The result of the Committee's recommendation would be simply to negative the suggestion in the dicta in the Times-Picayune case to the effect that the existence of a patent automatically (or at least prima facie) creates the market control necessary for tying clause illegality under the antitrust laws.

The third implicit assumption is that, as a general rule, a liberal licensing policy on the part of the patent owner is a virtually complete defense to patent antitrust charges. In other words, since it is exclusivity which is the whole substance of the patent grant (and the real focal point of antitrust complications), a liberal policy by the owner of waiving that exclusivity and permitting access of qualified applicants to his invention should eliminate all but the most vicious and willful types of antitrust situations. This assumption is most evident in the treatment of the problem of patent interchange. It is basically a very simple, practical and realistic approach to an otherwise most complicated area. Here again, it is essential to draw upon a rule of reasonableness in the examination into the validity of various patent practices as applied to industrial reality. It was just such an analysis which underlay the approach of the Supreme Court in Standard Oil Company (Indiana) v. United States, ${ }^{15}$ the Gasoline-Cracking case.

The process of analysis thus suggested by the Report has as perhaps its outstanding merit the fact that it arrives at a very realistic and very simple solution to the problems posed by patent interchange agreements. If a court finds an interchange to have been illegally erected or operated in an improper fashion, the probable remedy would be to order the licensing of the combined patents to all applicantsa remedy which accomplishes a complete freeing of the art involved in the interchange. It is self-evident that where the participants in the interchange themselves provide for the same ready availability of the combined patents, they have for all practical purposes accomplished all that a court decree would do..$^{16}$ In an area of such acute and diffi-

15. 283 U.S. 163 (1931).

16. See, in support of this recommendation, address by Diggins, Licenses, Cross-Licenses and Interchanges, ABA Annual Meeting, Aug. 22, 1955. 
cult legal niceties as are involved in a patent interchange, such a simple and easily applied yardstick is refreshing indeed. The Report in effect has recommended that the price which patent owners must pay for the privilege of assembling their individual monopolies into a patent interchange is the ready availability of those patents on a practical basis. The price of the interchange of patents is, in effect, the surrender of the patentee's right of exclusion.

The foregoing assumptions constitute the non-statements which are fundamental to the thinking of the Committee and which are assumed as a basis and background for the contents of the Report.

The second category of non-statements are those which were beyond the subject assigned to the Committee and hence form no part of the area of understanding between the writers and the readers. In this category there is one very important area of omission. The charter given to the Committee in its study of the problems of patents and the antitrust laws expressly excluded inquiry into the theoretical soundness or of the practical value of the patent system. For purposes of our study, the Committee concluded that its assignment was to assume that soundness and that value, and it had, of course, "judicial notice" of the very convincing demonstration of the striking way in which inventions have played a part in the spurring of industrial progress in the past century. It must be borne in mind, however, that the fact of any such value or soundness was by no means agreed on or the result of any meeting of the minds of the Committee members. It was simply assumed arguendo. This fact is particularly important when inquiry is made as to the current status of the patent system and of its adequacy for the future. For, regardless of its contributions in the past, if it is to be justified as an instrument for future progress, the patent system must continue to show readiness to contribute in the years ahead.

Although such a query was clearly not within the province of the Attorney General's Committee, it is pertinent to inquire whether the current role of the patent system in furthering competition is indeed in equipoise with that of antitrust policy in maintaining it; whether the onslaught of ideological opposition in recent years has affected either the scope or the effectiveness of the patent laws in the fulfillment of their intended purpose.

The creation in 1954 of the George Washington University Patent, Trade-Mark and Copyright Foundation may augur a thorough and valuable research undertaking in this important area. Already pilot projects are in process on such pertinent subjects as patent utilization, the value of the patent in the United States, and the effect 
of patents on the creation and growth of small industrial units. ${ }^{17}$ Perhaps a further inquiry could be whether the government's power to convey compulsory licenses to any government contractor has had any significant effect on the securing of patent protection on inventions of military or strategic importance.

The Atomic Energy Act of 1954 places an absolute prohibition on patents to the extent the inventions are useful in atomic weapons, ${ }^{18}$ permits the Atomic Energy Commission to take title to inventions or discoveries ". . . made or conceived under any contract, subcontract, arrangement, or other relationship with the Commission, regardless of whether the contract or arrangement involved the expenditure of funds by the Commission . . . "19 and grants to the Commission compulsory licensing authority with regard to patents "of primary importance" in the atomic energy field, the application for which shall have been filed before September 1, 1959, even though the invention is privately financed and developed. ${ }^{20}$ A study might well be made of the impact, real or potential, of the compulsory licensing sections and of the inexcusably vitiating provisions under which any inventor enters into "relationships" with the Commission at the peril of the loss of his patents. ${ }^{21}$

It may be hoped that an objective and factual study in areas such as these will point the way to an even greater contribution from the patent system of the future.

17. Address by Oppenheim, Patents and Antitrust: Peaceful Coexistence?, ABA Annual Meeting, Aug. 22, 1955.

18. 60 SтAт. 768 (1946), as amended, 42 U.S.C. \$2181 (Supp. II, 1955).

19. Id. at 768,42 U.S.C. $\$ 2182$.

20. Id. at 768-69, 42 U.S.C. $\$ 2183$.

21. Such a study is apparently to be forthcoming at the next session of Congress. See address by Representative W. Sterling Cole, The Need for Revision of Compulsory Patent Provisions of the Atomic Energy Act of 1954, Federal Bar Association-Bureau of National Affairs, Inc., Washington, D.C., Sept. 22, 1955. Referring to $\$ 152$ (60 STAT. 768 (1946), 42 U.S.C. \$2182 (Supp. II, 1955)), Representative Cole said: ". . the past year has shown that this section needs to be revised." 